\title{
Hic-5 regulates an epithelial program mediated by PPAR $\gamma$
}

\author{
Stavit Drori, ${ }^{1,4}$ Geoffrey D. Girnun, ${ }^{1,4}$ Liqiang Tou, ${ }^{2}$ Jeffrey D. Szwaya, ${ }^{1}$ Elisabetta Mueller, ${ }^{1}$ \\ Xia Kia, ${ }^{3}$ Ramesh A. Shivdasani, ${ }^{2,3}$ and Bruce M. Spiegelman ${ }^{1,5}$ \\ ${ }^{1}$ Dana-Farber Cancer Institute and the Department of Cell Biology, Harvard Medical School and ${ }^{2}$ Departments of Medical \\ Oncology and Cancer Biology, Dana-Farber Cancer Institute, and the Department of Medicine, Harvard Medical School, \\ Boston, Massachusetts 02115, USA; ${ }^{3}$ Department of Medicine, Brigham and Women's Hospital, \\ Boston, Massachusetts 02115, USA
}

\begin{abstract}
PPAR $\gamma$ is a dominant regulator of fat cell differentiation. However, this nuclear receptor also plays an important role in the differentiation of intestinal and other epithelial cell types. The mechanism by which PPAR $\gamma$ can influence the differentiation of such diverse cell lineages is unknown. We show here that PPAR $\gamma$ interacts with Hic-5, a coactivator protein expressed in gut epithelial cells. Hic-5 and PPAR $\gamma$ colocalize to the villus epithelium of the small intestine, and their expression during embryonic gut development correlates with the transition from endoderm to a specialized epithelium; expression of both these factors is reduced in tumors. Forced expression of Hic-5 in colon cancer cells enhances the PPAR $\gamma$-mediated induction of several gut epithelial differentiation/maturation markers such as L-FABP, kruppel-like factor 4 (KLF4), and keratin 20. siRNA directed against Hic-5 specifically reduces PPAR $\gamma$-mediated induction of gut epithelial genes in colon cells and in an ex vivo model of embryonic gut differentiation. Finally, forced expression of Hic-5 during 3T3-L1 preadipocyte differentiation inhibits adipogenesis while inducing inappropriate expression of several mRNAs characteristic of gut epithelium in these mesenchymal cells. These results indicate that Hic 5 is an important component in determining an epithelial differentiation program induced by PPAR $\gamma$.
\end{abstract}

[Keywords: Hic-5; ARA55; PPAR $\gamma$; differentiation; selective-coactivator; gut-epithelial]

Supplemental material is available at http://www.genesdev.org.

Received July 16, 2004; revised version accepted December 8, 2004.

$\operatorname{PPAR} \gamma$ is a member of the nuclear receptor superfamily that functions in a heterodimeric complex with RXR (for review, see Spiegelman 1998). While the identity of the natural, endogenous ligand for this receptor is not clear, PPAR $\gamma$ is the functioning receptor for the antidiabetic thiazolidinedione drugs such as rosiglitazone and pioglitazone (Forman et al. 1995; Lehmann et al. 1995). PPAR $\gamma$ is a dominant regulator of fat cell differentiation, being both necessary and sufficient for this process (for review, see Lowell 1999; Rosen et al. 2000). Expression and ligand activation of PPAR $\gamma$ converts most fibroblastic cells into adipocytes (Tontonoz et al. 1994; Hu et al. 1995). Conversely, cells or animals lacking PPAR $\gamma$ show a complete loss of fat cells and fat tissue development (Barak et al. 1999; Kubota et al. 1999; Rosen et al. 1999).

Although PPAR $\gamma$ is expressed at highest levels in adipose tissues, it is also expressed at significant levels in a number of epithelial cell types, including several that are

\footnotetext{
${ }^{4}$ These authors contributed equally to this work.

${ }^{5}$ Corresponding author.

E-MAIL bruce spiegelman@dfci.harvard.edu; FAX (617) 632-5363.

Article and publication are at http://www.genesdev.org/cgi/doi/10.1101/ gad. 1240705 .
}

important in human cancer, such as colon (Mansen et al. 1996; Sarraf et al. 1998; Lefebvre et al. 1999), breast (Mueller et al. 1998), and prostate (Kubota et al. 1998; Mueller et al. 2000). Ligand activation of this receptor in human cancer cells from these tissues resulted in slowing of growth and an increase in cellular maturation (for reviews, see Koeffler 2003; Michalik et al. 2004). For example, PPAR $\gamma$ activation in human colon cancer cells reduces cell growth and induces multiple RNAs associated with a more differentiated phenotype, such as keratins 18,19 , and 20 and carcinoembryonic antigen (CEA) family members (Sarraf et al. 1998; Gupta et al. 2001). There is also an alteration in cell morphology, including an increase in cytoplasmic to nuclear ratio, consistent with a more differentiated phenotype (Sarraf et al. 1998).

The notion that PPAR $\gamma$ can alter the growth and differentiation state of epithelial cells has led to a number of studies of its potential role in the cause and treatment of cancer. Although agonist treatment of animals suggests possible both pro- or anticancer properties in the colon (Lefebvre et al. 1998; Saez et al. 1998; Sarraf et al. 1998), genetic studies unambiguously demonstrate that $\operatorname{PPAR} \gamma$ functions as a tumor suppressor in chemically induced colon carcinogenesis in mice /Girnun et al. 
2002). Human clinical trials have shown that application of a PPAR $y$ ligand to humans with certain forms of liposarcoma yielded impressive histological evidence of tumor differentiation (Demetri et al. 1999); trials of PPAR $\gamma$ ligands as a monotherapy in several advanced human malignancies have shown no efficacy (Kulke et al. 2002; Burstein et al. 2003). Taken together, these studies suggest that PPAR $\gamma$ may play an important role in the differentiated states of several forms of epithelia, whereas the use of PPAR $\gamma$ agonists in the human cancer clinic may be limited to the treatment of early stage disease, or in combination with other drugs.

The apparent ability of PPAR $y$ to promote the differentiation and maturation of fat cells of mesenchymal origin and cells of epithelial origin raises interesting issues. Because PPAR $\gamma$ and its heterodimeric partner RXR are essentially identical in all of these tissues, this suggests that the execution of radically different genetic programs must occur as a consequence of other molecules that interact, directly or indirectly, with PPAR $\gamma$. Recent data have indicated that coactivator proteins, such as PGC1 $\alpha$ or myocardin, can dramatically influence the activity of nuclear receptors and other transcription factors, thereby influencing cell fate (Puigserver et al. 1998; Wang et al. 2001; Yoon et al. 2001; Yoshida et al. 2003). We show here that intestinal epithelial cells contain a coactivator protein, Hic-5, that stimulates PPAR $\gamma$ transcriptional activity. Moreover, this factor promotes an epithelial-maturation activity when combined with PPAR $\gamma$ in malignantly transformed epithelial cells, and fetal small intestine. Hic-5 can even stimulate expression of PPAR $\gamma$-dependent epithelial genes when expressed in preadipose cells.

\section{Results}

\section{Hic-5 binds and coactivates PPAR $\gamma$}

We considered the possibility that PPAR $\gamma$ may execute a particular program related to gut epithelial biology through the function of a tissue-selective coactivator protein. To identify candidate cofactors of $\operatorname{PPAR} \gamma$, we used a yeast two-hybrid assay to screen a human colon cancer cDNA library, using the ligand-binding domain (LBD) of PPAR $\gamma$ as bait. Two positive clones, each isolated multiple times, were identified as Hic-5, previously described as a TGF $\beta$-inducible gene (Shibanuma et al. 1994) and as a LIM-domain coactivator of the androgen receptor in prostate cells, also known as androgen receptor activator 55 (ARA55) (Fujimoto et al. 1999). Hic-5 is known to be expressed in several cell types of epithelial origin: prostate, lung, small intestine, and colon (Shibanuma et al. 1994; Zhang et al. 2000). This pattern of expression along with the ability of Hic-5 to coactivate various nuclear receptors (Fujimoto et al. 1999; Yang et al. 2000) and to be regulated by TGF $\beta$, an important regulator of the colonic epithelium, prompted our further studies.

The ability of Hic-5 to affect PPAR $\gamma$ transcriptional activity was determined using Bosc cells transiently transfected with a luciferase reporter gene linked to a multiple copies of a PPAR $\gamma$ response element (DR1). Hic-5 potentiated PPAR $\gamma$ activity in a ligand-dependent manner (pioglitazone $1 \mu \mathrm{M}$ ) (Fig. 1A). PGC1 $\alpha$, a bona fide coactivator of PPAR $\gamma$ (Puigserver et al. 1998), was used as a positive control and showed similar stimulation of PPAR $\gamma$ transcriptional activity, although as expected, this activity was largely ligand independent (Fig. 1A).

To determine whether the ability of endogenous Hic-5 to increase PPAR $\gamma$ activity results from a physical interaction, as implied by the yeast two-hybrid results, cells were transfected with either Flag-tagged PPAR $\gamma$ or a control vector. As a positive control for physical interaction, cells were cotransfected with a tagged PPAR $y$ and PGCl $\alpha$. We could not use endogenous PGCl $\alpha$ in this experiment because this coactivator cannot be detected in Bosc cells. As shown in Figure 1B, endogenous Hic-5 coprecipitated with PPAR $\gamma$ in the presence of rosiglitazone, while PGCl $\alpha$ coprecipitated with PPAR $\gamma$ in a ligand-independent manner. The domains involved in the interaction between Hic-5 and PPAR $\gamma$ were determined using a modified GST pull-down assay. Bosc cells were transiently transfected with plasmid vectors expressing different domains of Hic-5 fused to gfp. The Cterminal and wild-type gfp-Hic-5 have been reported to be localized primarily to focal adhesion sites by fluorescent microscopy (Fujita et al. 1998). In contrast, N-terminal gfp-Hic-5 is localized diffusely throughout the cell. We observed similar localization patterns and did not see changes in localization in the presence of PPAR $\gamma$ ligands (data not shown). Lysates from these cells were then incubated with GST fused to full-length PPAR $\gamma$. After washing, proteins were eluted and were immunoblotted for gfp. Figure 1C shows that GST-PPAR $\gamma$ binds to full-length Hic-5. However, a Hic-5 $\Delta$ LIM protein containing amino acids 1-208 was not coprecipitated with PPAR $\gamma$, while Hic-5(209-444) was coprecipitated with PPAR $\gamma$. The domains of Hic-5 responsible for the interaction with PPAR $\gamma$ were further mapped by using fragments of Hic-5 translated in vitro. Figure 1D shows that GST-PPAR $\gamma$ binds to the full-length Hic-5(1-444) but fails to interact with the Hic-5(1-208), $\Delta$ LIM, in a similar pattern shown in Figure 1C. Various combinations of LIM motifs (LIM1, LIM1-2, LIM2-4) were sufficient to restore Hic-5 binding to PPAR $\gamma$ (Fig. 1D). These data imply that each LIM motif in Hic-5 might contribute to its interaction with PPAR $\gamma$. This finding resembles those in a recent study showing that another LIM domain protein, FHL2, binds to the androgen receptor through multiple LIM domains (Muller et al. 2000).

\section{Hic-5 and PPAR $\gamma$ are coexpressed in normal and malignant gut development}

Gut endoderm develops into a structured epithelium between embryonic days 13 and 15 (E13 and E15) (Simon and Gordon 1995). We investigated whether Hic-5 and PPAR $\gamma$ were coexpressed during gut development, using a fetal mouse intestine as a model. After microscopic dissection of intestines at E12.5 to E17.5, RNA was ex- 
Drori et al.

tracted and relative levels of Hic-5, PPAR $\gamma$ mRNA, and several other markers of gut development were determined. As shown in Figure 2A, PPAR $\gamma$ mRNA increases 2.2-fold between E12.5 and E13.5 and a further fourfold between E13.5 and E15.5. Hic-5 mRNA levels also increase twofold between E12.5 and E13.5 (Fig. 2A). This increase in PPAR $\gamma$ and Hic-5 transcripts correlates with the induction of several molecular markers of gut epithelial maturation between E13.5 and E15.5 including keratin 18, keratin 19, and liver fatty-acid-binding protein (L-FABP) (Fig. 2A). To further examine whether PPAR $\gamma$ and Hic-5 colocalize in the intestine, paraffinembedded sections of intestine from E13.5, E15.5, E17.5, and 2-wk-old mice were analyzed by immunohistochemistry. As shown in Figure 2B, PPAR $\gamma$ protein is localized mainly to the epithelium of embryonic developing gut and in the mucosal lining of the adult villus, with a gradient of increasing expression toward the villus tip (Fig. 2B). Hic-5 shows a similar graded pattern of expression in epithelial cells (Fig. 2A), although its expression is not restricted to the epithelial layer in agreement with previous reports (Fig. 2B; Shibanuma et al. 1994; Yuminamochi et al. 2003). Importantly, these data illustrate that although Hic-5 expression pattern in the gut is broader than the expression of PPAR $\gamma, \operatorname{PPAR} \gamma$ and Hic-5 are colocalized only in the gut epithelial layer and are induced during epithelium development.

We also investigated Hic-5 and PPAR $\gamma$ expression in pathological development, particularly in epithelial tumorgenesis. Mice were treated with azoxymethane (AOM), a chemical that induces colon tumors, as previ-

Figure 1. Hic-5 binds and coactivates PPAR $\gamma$ in a ligand-depended manner $(A)$ Bosc cells were transiently cotransfected with $50 \mathrm{ng}$ of expression vector for PPAR $\gamma$ and $50 \mathrm{ng}$ of a luciferase reporter plasmid with three PPAR $\gamma$ response elements (DR1-sites), in the presence of $250 \mathrm{ng}$ Hic-5 or $100 \mathrm{ng} \mathrm{PGC1} \alpha$ expression vectors. Empty vector was used as a control. The following day cells were treated with $1 \mu \mathrm{M}$ pioglitazone (Pio). Cell lysates were then analyzed for relative transcriptional activity, and data were normalized to $\beta$-gal activity, derived from a cotransfected $\beta$-gal expressing vector. Values were expressed relative to activation of empty vector and presented as mean \pm SE of three different experiments. (B) Coimmunoprecipitation assay. Bosc cells were transfected with either control vector or vector expressing Flag-PPAR $\gamma$. Cell lysates were then incubated with beads bound to an antibody directed against the Flag epitope. The interaction between Flag-PPAR $\gamma$ and endogenous Hic-5 was tested in the presence and absence of rosiglitazone. Ectopic expression of gfp-PGC1 $\alpha$ was used as a positive control for binding to PPAR $\gamma .(C)$ Bosc cells were transiently transfected with various gfp-Hic- 5 alleles. The cells were harvested, and extracts were incubated with immobilized GST$\operatorname{PPAR} \gamma$, which was purified from Sf21 baculovirus cells in the presence of PPAR $\gamma$ ligand troglitazone (Tro). After washing, bound proteins were eluted and separated by SDS-PAGE, followed by Western blotting using an anti-gfp antibody. (D) In vitro interaction assay. Either GST or GST-PPAR $\gamma$ was incubated with ${ }^{35}$ S-labeled Hic-5 alleles (shown on the right panel). SRC-1 was used as positive control to show in vitro binding to $\operatorname{PPAR} \gamma$. ously described (Burdette Walter 1970; Girnun et al. 2002). Hic-5 and PPAR $\gamma$ mRNA levels were analyzed in colon tumors and compared with those in adjacent normal tissue, using quantitative real-time RT-PCR. Figure 2C shows that PPAR $y$ expression was decreased by almost $70 \%$ in the tumor compared with the normal epithelial tissue. Hic-5 levels were decreased by $>50 \%$. mRNA of paxillin, a Hic-5 homolog that has been implicated as a positive regulator of cell survival and motility (Schaller 2001; Hanks et al. 2003), was increased 2.5-fold in these tumors. As expected, several molecular markers of colon differentiation, such as keratin 20 (Calnek and Quaroni 1993; Moll et al. 1993) and kruppel-like factor 4 (KLF4), a transcription factor linked to epithelial differentiation (Chen et al. 2003), were decreased in the tumor tissue. Taken together, these data show a correlation between Hic-5 and PPAR $\gamma$ levels and levels of certain gut differentiation markers.

\section{Hic-5 enhances PPAR $\gamma$-mediated induction of epithelial genes, in colon cancer cells}

A gene-array analysis was used to study the program of endogenous gene expression induced by PPAR $\gamma$ in poorly

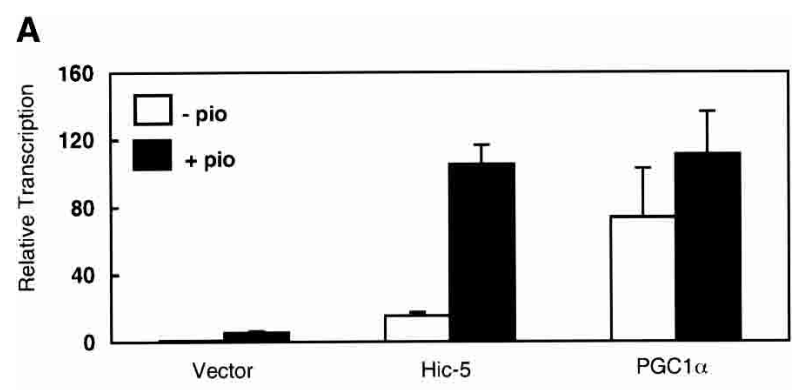

B
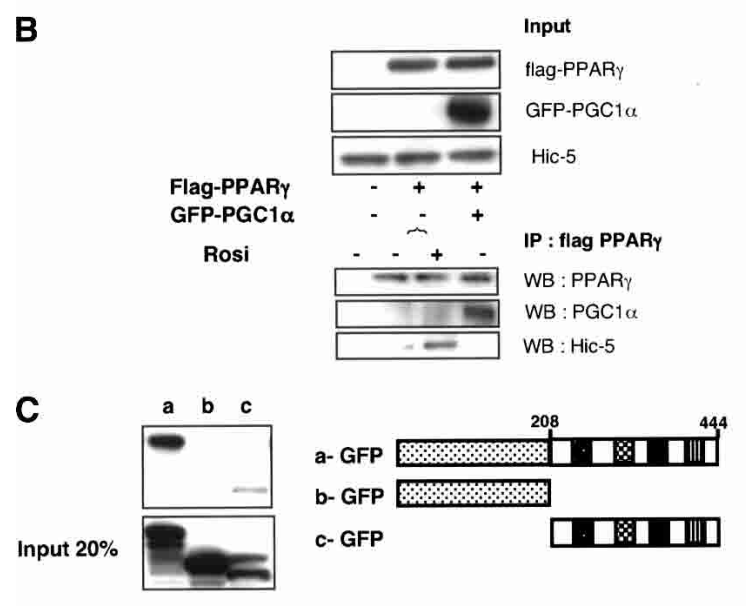

D

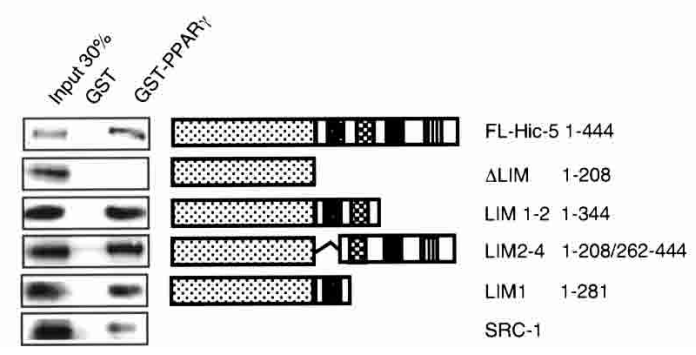




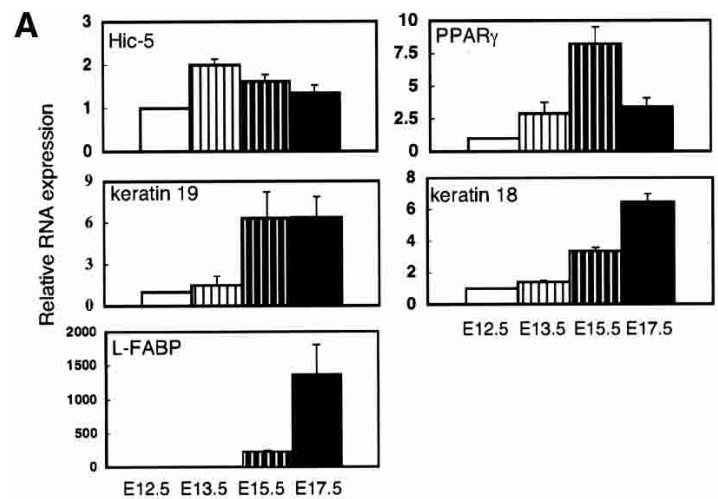

B
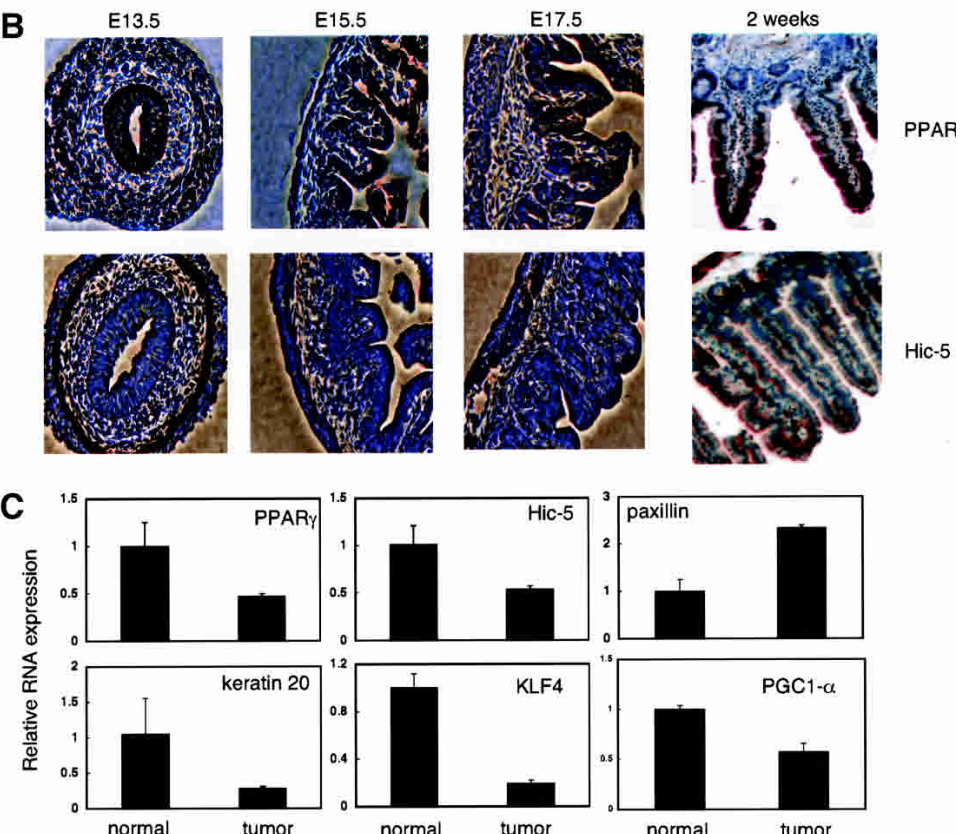

differentiated epithelial cells. Moser human colon cancer cells were treated in the presence and absence of rosiglitazone for $14 \mathrm{~h}$. Genes that showed statistically significant differences in expression between rosiglitazone-treated and -untreated cells were then classified according to their function: epithelial differentiation, cell adhesion, tumor suppressors, oncogenes, lipid metabolisms, and insulin signaling (Supplementary Fig. 1). Since these studies focused on expression of a gut epithelial program, genes classified as related to epithelialselective functions or cell adhesion were further studied. To determine the role of Hic-5 in the expression of these epithelial cell-selective genes, Moser human colon cancer cells were then retrovirally infected with either a vector expressing Hic-5 or an empty vector, and treated with rosiglitazone; as shown earlier, these cells express relatively high amounts of endogenous PPAR $\gamma$ protein (Sarraf et al. 1998). Figure 3A shows that in cells containing only the control vector, rosiglitazone induced several mRNAs characteristic of gut epithelium identified in our gene array analysis, such as keratin 20 (Moll et al. 1993; Gupta et al. 2001) L-FABP (Roth et al. 1990; Gupta et al. 2001), and KLF4 (Chen et al. 2003).
PPAF

Figure 2. Hic-5 and PPAR $\gamma$ are coexpressed in normal and malignant gut development. (A) Small intestines from mouse embryos were dissected at different stages of embryonic development, and total RNA was extracted. The level of expression of PPAR $\gamma$, Hic-5, keratin 19 , keratin 18 , and L-FABP was analyzed by using real-time RT-PCR assay. (B) Immunohistochemistry of PPAR $\gamma$ and Hic-5 in sections of embryonic and adult mouse small intestines. Brown color indicates positive staining; blue denotes nuclear counter-staining. $(C)$ Mice were treated with AOM as described earlier (Girnun et al. 2002). Colonic tumors and adjacent tissue were harvested, and RNA was extracted. Levels of PPAR $\gamma$, Hic-5, paxillin, keratin 20 KLF4, and PGC1 $\alpha$ were analyzed by real-time RT-PCR. The levels of RNA expression were normalized with TBP and are mean \pm SD. $(n=5)$. Statistical analysis was done by using Student's $t$-test. $\left(^{\star}\right) p<0.01$

Without the addition of a PPAR $\gamma$ ligand, expression of Hic-5 had no significant effect on these epithelial transcripts, and cells underwent no obvious morphological changes. However, the combination of Hic-5 expression and addition of rosiglitazone resulted in an increased induction of each of these epithelial genes (Fig. 3A). The increase in KLF4 and keratin 20 was twofold compared with control cells treated with rosiglitazone, while Hic5 -mediated increase in L-FABP mRNA was $~ 40$-fold. In contrast, Hic-5 made no detectable contribution to the induction of adipophilin (ADRP) (Fig. 3A), a PPAR $\gamma$ target gene known to be induced in adipogenesis that is also expressed in colon cancer cells (Gupta et al. 2001). Taken together, these data suggest that certain aspects of a specific program of gut epithelial maturation are executed through Hic-5/PPAR $\gamma$ cooperation. However, induction of certain other PPAR $\gamma$ target genes implicated in cell adhesion such as BPG (CEACAM1), CEA (CEACAM5) (Sarraf et al. 1998; Gupta et al. 2001), and annexin A1 (Karasik et al. 1988) was not affected by cooperation between ectopic Hic-5 and the PPAR $\gamma$ ligand (Fig. 3B).

We next asked whether the molecular phenotypes observed were specific for Hic-5 or occurred with the el- 

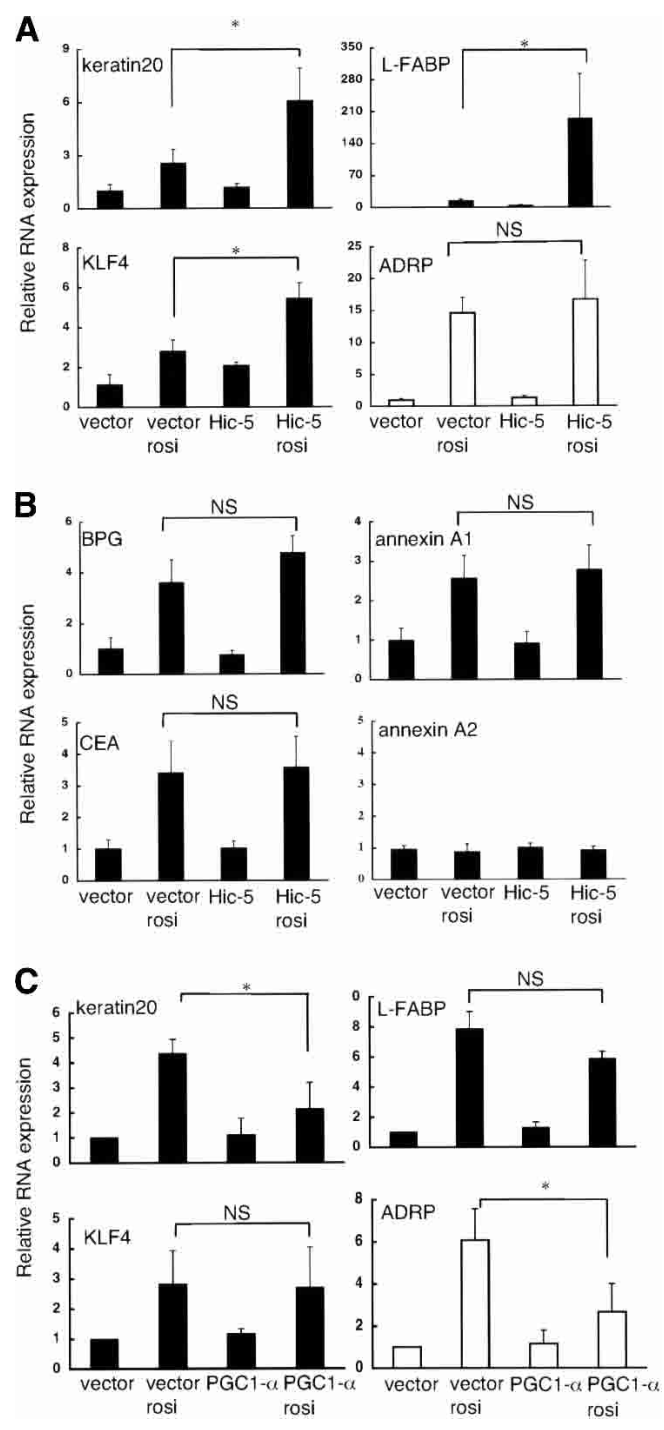

Figure 3. Ectopic expression of Hic-5 enhances PPAR $\gamma$-mediated induction of several epithelial markers in colon cancer cells. (A) Human colon cancer cells (Moser) were infected with a control retrovirus or a retrovirus expressing Hic-5. Cells were treated with or without $1 \mu \mathrm{M}$ rosiglitazone and were then harvested, and RNA was extracted. Levels of mRNA for keratin 20, L-FABP, KLF4, and ADRP were quantified by real-time RTPCR. Statistical analysis was done using Student's $t$-test. $\left({ }^{\star}\right)$ $p<0.05$; (NS) not significant. (B) Cells were treated as described in $A$. Levels of mRNA for BPG, CEA, annexin A1, and annexin A2 were determined by real-time RT-PCR analysis. Statistical analysis was done using Student's $t$-test. (NS) Not significant. (C) Moser cells were infected with either gfp or PGC1 $\alpha$ expressing adenovirus. Cells were treated with or without $1 \mu \mathrm{M}$ rosiglitazone and were then harvested, and RNA was extracted. Levels of mRNA for keratin 20, L-FABP, KLF4, and ADRP were quantified by real-time RT-PCR. Statistical analysis was done using Student's $t$-test. $\left(^{\star}\right) p<0.05$; (NS) not significant.

evation of any PPAR $\gamma$ coactivator. We therefore expressed another PPAR $\gamma$ coactivator, PGC1 $\alpha$ and examined its effects on epithelial gene expression. Interestingly, PGC1 $\alpha$ was recently described to be down-regulated in human colon tumors (Feilchenfeldt et al. 2004). Figure $3 \mathrm{C}$ shows that PGC1 $\alpha$ did not increase the PPAR $\gamma$-mediated induction of epithelial target genes. In fact, PGC1 $\alpha$ expression decreased PPAR $\gamma$-mediated induction of keratin 20, and ADRP (Fig. 3C). These data indicate some selectivity for Hic-5 in mediating PPAR $\gamma$ induction of epithelial-selective genes.

$N$ terminus of Hic-5 functions as a dominant-negative allele and alters epithelial gene expression

Both the $\mathrm{C}$ and $\mathrm{N}$ termini of Hic- 5 were previously suggested to function as dominant-negative (DN) alleles of Hic-5 (Fujimoto et al. 1999; Kasai et al. 2003). We therefore analyzed the ability of these fragments to alter PPAR $\gamma$-mediated transcription. As shown in Figure 4A, the C-terminal domain (209-444) retains some ability to coactivate PPAR $\gamma$, although the magnitude of this activity is much lower than that seen with full-length Hic-5. In contrast, the $\mathrm{N}$ terminus of Hic-5(1-208) lacks the ability to coactivate PPAR $\gamma$ (Fig. 4A). To evaluate whether either of these Hic-5-derived proteins might have a suppressive effect on wild-type Hic-5 activity, the full-length protein was expressed with increasing concentration of either the $\mathrm{N}$-terminal or $\mathrm{C}$-terminal halves (Fig. 4B). Coexpression of Hic-5 and its N-terminal fragment resulted in a dose-dependent inhibition of PPAR $\gamma$ coactivation (Fig. 4B, lanes 5-10), while this fragment had no significant effect on the ligand activation of PPAR $\gamma$ in the absence of added wild-type Hic-5 (Fig. 4A). In contrast, coexpression of full-length Hic-5 with increasing amounts of the C-terminal fragment of Hic-5 resulted in a minor increase in PPAR $\gamma$ coactivation (Fig. 4B, lanes 11-16). These results suggest that the N-terminal fragment of Hic-5 can function as a dominant-negative allele and can interfere with Hic-5 coactivation of PPAR $\gamma$. Importantly, this fragment does not appear to interfere significantly with PPAR $\gamma$ activity in the absence of wild-type Hic-5.

We examined the effect of this dominant-negative allele of Hic-5 on expression of keratin 20, a specific marker of enterocyte maturation (Moll et al. 1993; Gupta et al. 2001), in Moser human colon cancer cells. Moser cells were retroviraly infected with a vector expressing Hic-5, the domonant-negative allele of Hic-5 or a control gfp protein (Fig. 4C), and cells were then treated with or without the PPAR $\gamma$ agonist pioglitazone. After $2 \mathrm{~d}$ of treatment, the induction of keratin 20 mRNA and protein was analyzed using either real-time RT-PCR (Fig. 4C, upper panel) or by Western blot analysis (Fig. 4C, lower panel). As shown in Figure 3A, expression of wildtype Hic-5 enhanced the PPAR $\gamma$-mediated induction of keratin 20. Expression of the dominant-negative allele of Hic- 5 completely abolished PPAR $\gamma$-mediated induction of keratin 20 at the mRNA and protein levels (Fig. 4C). Interestingly, TGF $\beta$, a well-known inducer of the Hic-5 protein (Shibanuma et al. 1994) also enhanced PPAR $\gamma$ mediated induction of keratin 20, an effect also suppressed by expression of the dominant-negative version of Hic-5 (Fig. 4C). However, addition of TGF $\beta$ could not 
A

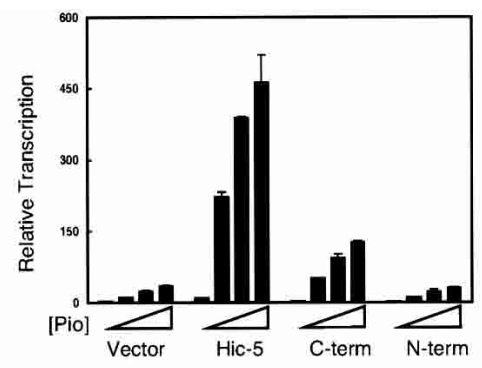

B

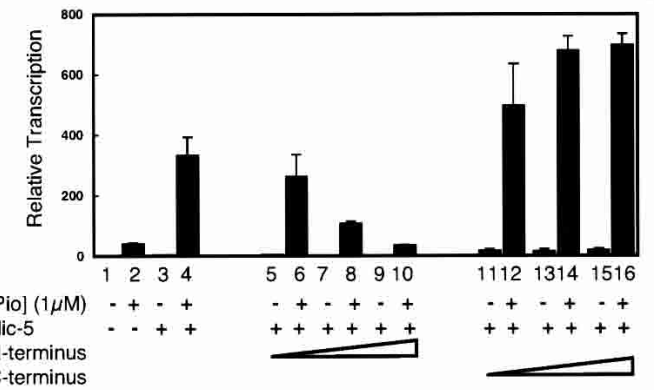

C

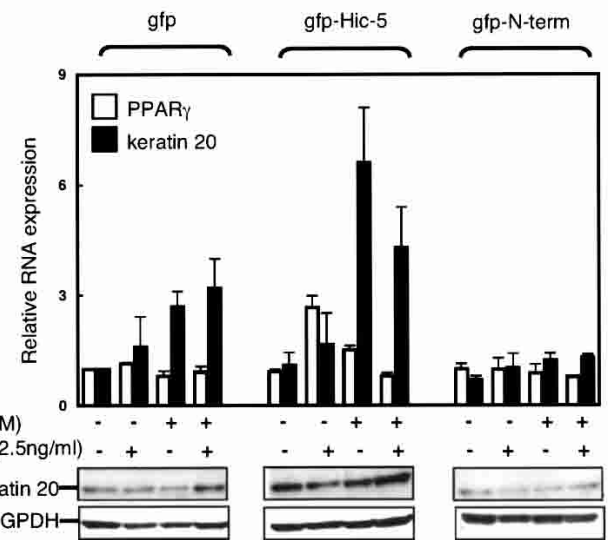

Figure 4. TGF $\beta$ enhances $\operatorname{PPAR} \gamma$ induction of keratin 20, while dominant-negative Hic-5 blocks it. $(A)$ Cos-1 cells were transiently cotransfected with $50 \mathrm{ng}$ expression vector for PPAR $\gamma, 50$ ng luciferase reporter plasmid with three PPAR $\gamma$ response elements (DR1-luc) in the presence of $250 \mathrm{ng}$ gfp-Hic5, 400 ng gfp-C terminus Hic-5(209-444), gfp-N terminus Hic5(1-208) expression vectors, or gfp expressing vector as a control. Cells were treated with increasing concentrations of pioglitazone (Pio) as shown. Cell lysate were then analyzed for relative transcriptional activity, as described in Figure 1A. (B) Cos- 1 cells were transiently tranfected and treated as described in $A$. To determine potential dominant-negative activities, Hic-5 expressing vector (100 ng) was cotransfected with increasing amount of either gfp- $\mathrm{N}$ terminus Hic-5 or gfp-C terminus Hic-5(100-400 ng). (C) Moser cells transduced with retroviral expressing Hic-5, dominant-negative Hic-5 (gfp-N terminus), or gfp were incubated with or without TGF $\beta$ or PPAR $\gamma$ ligand (pioglitazone). After $2 \mathrm{~d}$, total RNA and protein were extracted. (Top) Relative keratin 20 and PPAR $\gamma$ mRNA levels were analyzed by real-time RT-PCR. Values of keratin 20 and PPAR $\gamma$ were normalized to expression level without treatment in control cells, corrected to $\beta$-actin and were mean \pm SE of three different experiments. (Bottom) Protein lysates were extracted and separated by SDS-PAGE gels. Keratin 20 and GPDH levels were analyzed by Western blot using keratin 20 and GPDH antibodies respectively. GPDH levels are shown as a loading control. further enhance PPAR $\gamma$-mediated induction of keratin 20 in the presence of exogenous expressed Hic-5, consistent with the notion that the induction of Hic- 5 by TGF $\beta$ might be a major link between the TGF $\beta$ and PPAR $\gamma$ pathways in colon cancer.

\section{siRNA directed against Hic-5 inhibits PPAR induction of epithelial-selective genes}

siRNA directed against Hic-5 were designed and cloned into a retroviral vector. Scrambled oligonucleotides cloned into the same vector were used as a control. Moser cells were infected with both control and siRNA retroviruses. siRNA against Hic-5 was able to downregulate Hic- 5 mRNA levels by at least $60 \%$ (Fig. 5A) and had an even greater effect on the level of Hic-5 protein (Fig. 5A, inset). Infected cells were treated with or without rosiglitazone. As expected, rosiglitazone was again able to induce L-FABP, KLF4, keratin 20, and ADRP in control cells (Fig. 5B). The expression of the siRNA against Hic-5 did not significantly change the level of these genes in the absence of PPAR $\gamma$ agonist (Fig. 5B). However, the ability of the PPAR $\gamma$ ligand-mediated induction of each transcript was dramatically decreased in cells expressing the siRNA against Hic-5, while the induction of ADRP was not affected (Fig. 5B). Together, these loss-of function data, using both a dominant-negative allele of Hic-5 and Hic-5-specific siRNA, indicate that Hic-5 and PPAR $\gamma$ cooperate specifically to induce multiple genes characteristic of gut epithelial differentiation.

To again evaluate the specificity of these effects, Moser cells were infected with either adenovirus expressing siRNA targeted against PGC1- $\alpha$ (siRNA- $\alpha$ ) (Koo et al. 2004), or a scrambled oligonucleotide, and treated with or without rosiglitazone. The level of PGCl $\alpha$ mRNA was reduced by $30 \%$ (Fig. 5C, left panel), and the mRNA for a well-known PGCl $\alpha$ target gene ERR $\alpha$ (Schreiber et al. 2003) was reduced by $>50 \%$ in cells infected with siRNA directed against PGCl $\alpha$ (siRNA- $\alpha$ ) (Fig. 5C, right panel). Figure 5D shows that the induction of PPAR $\gamma$ epithelial target genes KLF4, L-FABP, and keratin 20 is not affected in cells expressing siRNA directed against PGC1 $\alpha$. Taken together, these data indicate that Hic-5 but not PGC1 $\alpha$ is part of the transcriptional pathway inducing the set of epithelial target genes mediated by PPAR $\gamma$.

\section{Modulation of PPAR $\gamma$ and Hic-5 \\ levels in gut development}

Mice with total knock out of PPAR $\gamma$ are not viable, but heterozygous mice have normal viability (Barak et al. 1999; Kubota et al. 1999). Therefore we used small intestines from PPAR $\gamma$ heterozygous and wild-type mice (Akiyama et al. 2002) to examine the role of PPAR $\gamma$ in the normal process of gut epithelial differentiation. Figure $6 \mathrm{~A}$ shows that small intestines harvested from 

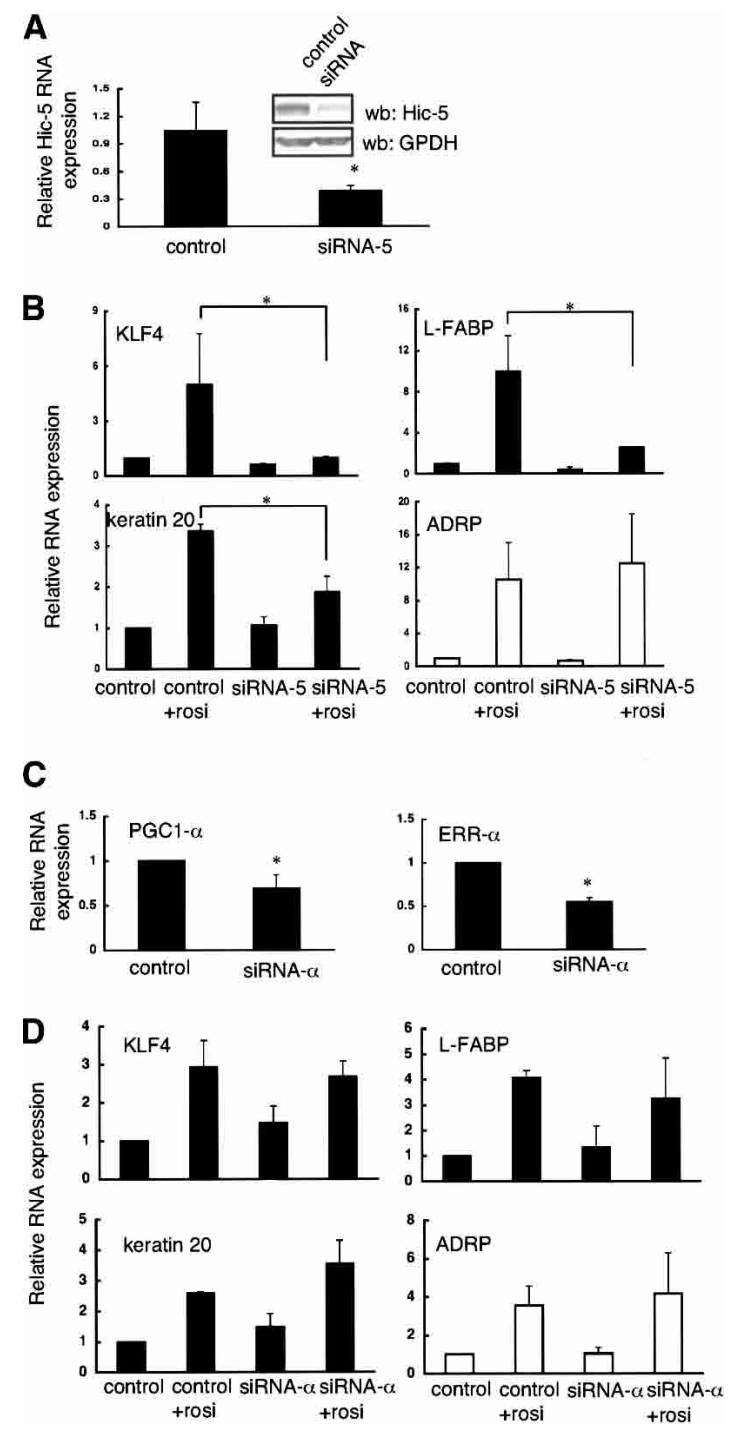

Figure 5. siRNA against Hic-5 inhibits PPAR $\gamma$ induction of certain epithelial genes. (A) Moser cells infected with siRNA expressing vector (pSuper-neo) directed against Hic-5 (siRNA-5) mRNA or scrambled oligonucleotides as a control. After antibiotic selection cells were treated with and without $1 \mu \mathrm{M}$ rosiglitazone. (Inset) RNA and proteins were isolated, and Hic-5 mRNA levels were determined by real-time RT-PCR and Western blot analysis. The levels of RNA expression were normalized with TBP and are mean \pm SD of three different experiments. Statistical analysis was done using Student's $t$-test. $\left({ }^{*}\right)$ $p<0.01$. (B) Cells were treated as described in $A$. RNA was isolated, and levels of mRNA for, KLF4, L-FABP, keratin 20, and ADRP were analyzed by real-time RT-PCR. Statistical analysis was done using Student's $t$-test. $\left(^{\star}\right) p<0.05$. (C) Moser cells infected with adenovirus expressing either siRNA directed against PGC1 $\alpha$ mRNA (siRNA- $\alpha$ ) (Koo et al. 2004), or scrambled oligonucleotide as a control. After $48 \mathrm{~h}$ cells were harvested, and levels of PGC1 $\alpha$ and its target gene ERR $\alpha$ were measured by real-time PCR. Analysis was done as described in $A$. $(D)$ Moser cells were infected as described in $C$. After infection cells were treated with or without rosiglitazone $(1 \mu \mathrm{M})$. Levels of KLF4, keratin 20, L-FABP, and ADRP were analyzed as described in $B$.
PPAR $\gamma$ heterozygous (PPAR $\gamma^{+/-}$) mice express 50\% less mRNA for PPAR $\gamma$ compared with small intestines from Ppary wild-type $\left(\mathrm{PPAR}^{+/-}\right)$mice (Fig. 6A, upper left panel). Importantly, small intestines from PPAR $\gamma^{+/-}$ mice also showed $50 \%$ reduction in the expression of several mRNA markers of gut epithelium (Fig. 6A): KLF4, keratin 20, and keratin 19 L-FABP, and keratin 18 mRNA levels showed the same trend, albeit, not statistically significant. These results further demonstrate a physiological role for PPAR $\gamma$ in gut epithelial differentiation.

We used an ex vivo embryonic model to study Hic-5 role during embryonic gut development, which has recently been described (Tou et al. 2004). Primitive guts were dissected from murine embryos and placed in a chemically defined media. When cultured over several days, these explants can undergo growth, peristalsis, and eventually cytodifferentiation as evidence by villus morphogenesis and changes in gene expression reminiscent of gut differentiation. This system allows the manipulation of specific genes, by injections of siRNA expression plasmids or mammalian expression plasmids into the lumen followed by electroporation. Importantly, the expression plasmids in this system have been shown to be targeted mainly to the evolving epithelium layer (Tou et al. 2004). The manipulation of Hic-5 levels is therefore expected to occur mainly in the epithelial layer despite the fact that Hic-5 is also present in the mesenchymal layer of the gut. We first injected embryonic guts with either plasmids expressing siRNA directed against Hic-5 (Fig. 6B, siRNA-5-I, siRNA-5-II) or plasmids expressing scrambled oligonucleotides as control (Fig. 6B, control). After electroporation, these embryonic small intestines were kept under in vitro differentiation conditions (Tou et al. 2004). After 2 d, protein lysates were harvested, and the levels of Hic-5 protein and epithelial markers were determined by Western blots analysis. Figure 6B shows that in total guts treated with siRNA directed against Hic-5, expressed $22 \%$ and $62 \%$ (siRNA-I and siRNA-II) less Hic-5 protein compared with fetal intestine electroporated with control plasmid. Since Hic-5 in the epithelium represents only a portion of the total Hic- 5 in the gut, the percentage reduction in the expression level is presumably somewhat larger than this value. These reductions in Hic-5 levels resulted in decreases in several epithelial markers; $42 \%$ and $86 \%$ reduction in keratin 19 and 54\% reduction in L-FABP (siRNA-5-II) expression levels. These data indicate that normal Hic-5 expression is required for the epithelial gene expression in the intact embryonic gut.

We also used the same ex vivo system to study the effects of ectopic Hic-5 expression. Figure 6C shows that Hic-5 mRNA levels were increased threefold in embryonic small intestines injected with Hic-5 expression vector compared with the control injected embryos. This increase caused a threefold increase in keratin 20 levels and a similar trend in KLF4 mRNA levels (Fig. 6C). Taken together, manipulation of Hic-5 expression levels in the fetal mouse intestine resulted in distinct modulation of gut epithelial gene expression. These data 
A
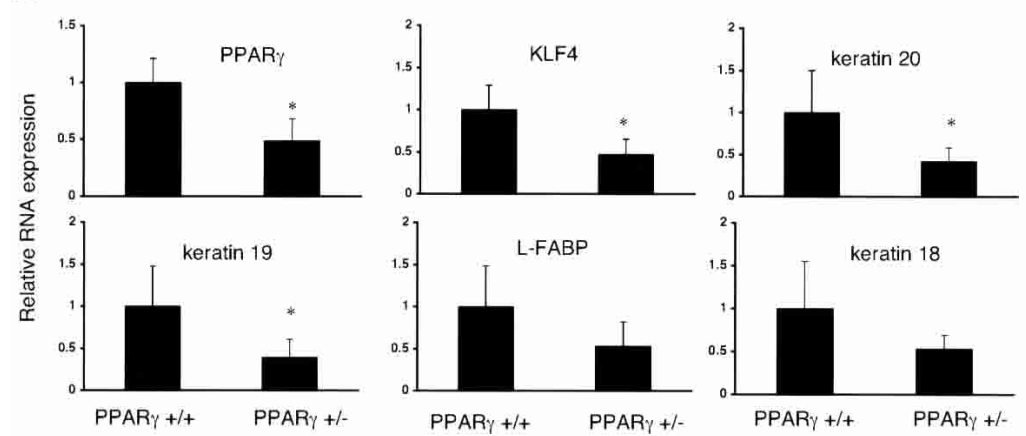

B

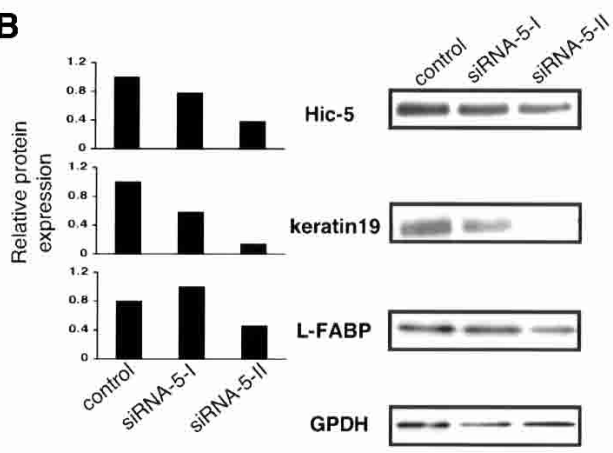

C

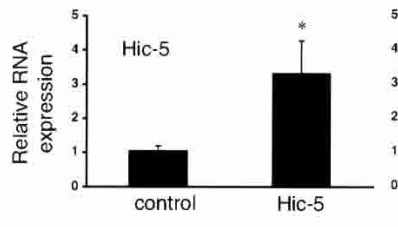

Figure 6. Modulation of PPAR $\gamma$ and Hic-5 expression in epithelial gut development. (A) Small intestines were isolated from PPAR $\gamma^{+/+}$and PPAR $\gamma^{+-}$mice (Akiyama et al. 2002). After RNA isolation levels of PPAR $\gamma$ keratin 20, keratin 19, keratin 18, KLF4, and L-FABP were determined using real-time RT-PCR analysis, as described in Figure $5(n=6)$. (B) Small-intestines were isolated from mice embryos between E12 and E13 and were injected with either siRNA directed against Hic-5 (siRNA-5-I, siRNA-5-II) or scrambled oligonucleotide expressing vector, followed by electroporation to express the plasmids in the epithelial layer. Embryonic small-intestines were then grown for $2 \mathrm{~d}$ ex vivo under differentiation condition, and protein lysates were harvested as described in Tou et al. (2004). Hic-5, keratin 19, and L-FABP protein levels were analyzed by Western blot analysis, using GPDH as loading control. Relative protein expression was determined by using densitometer analysis of the Western blot corrected for GPDH expression levels. This is a representative experiment $(n=5)$. $(C)$ Embryonic small intestines were isolated and treated as described in $B$, only Hic-5 expressing vector and an empty vector as a control were used. RNA was isolated, and Hic-5, keratin 20, and KLF4 mRNA levels were analyzed using real-time RT-PCR as described in Figure 5. strongly suggest a physiological role for Hic-5 in gut epithelial development.

\section{Expression of Hic-5 alters the program} of adipocyte differentiation.

Preadipocytes are mesenchymal cells that are ontologically far removed from epithelial cell lineages and are not known to express bona fide markers of epithelial cells. We therefore, examined the effects of forced Hic-5 expression during adipogenesis, a pathway where PPAR $\gamma$ plays a dominant role. 3T3-L1 preadipocytes were infected with either an empty retroviral vector or a Hic-5 expressing vector, and the resulting cells were subjected to a standard protocol of differentiation, with or without the addition of a PPAR $\gamma$ ligand for $4 \mathrm{~d}$. Figure 7A shows that while endogenous Hic-5 is expressed at detectable levels in 3T3-L1 preadipocytes, these levels decrease during differentiation. Interestingly, forced expression of Hic-5 inhibited morphological aspects of adipogenesis, as shown by phase contrast microscopy and by the accumulation of lipids, as illustrated by Oil-Red-O staining (Fig. 7B). Furthermore, several mRNAs characteristic of adipocyte differentiation, such as aP2, adipsin, and acrp30, were all reduced with forced Hic-5 expression. This effect was even more dramatic when PPAR $\gamma$ ligand was added to the differentiation mixture (Fig. 7C). Notably, the cells infected with empty vector do not express several mRNAs characteristic of gut epithelial differentiation, such as keratin 20, L-FABP, and KLF4. Expression of Hic-5 alone mildly increased the levels of these genes. However, when cells expressing Hic-5 were treated with rosiglitazone, robust expression of these epithelial genes was observed (Fig. 7C). These data indicate that Hic-5 and PPAR $\gamma$ can collaborate to induce inappropriate expression of genes characteristic of epithelial cells, even in a classical model of adipose differentiation.

\section{Discussion}

Although PPAR $\gamma$ is best known as a dominant regulator of fat cell differentiation, it also participates in the maturation and growth regulation of various epithelial cell lineages. Genes that constitute the fat cell differentiation program, such as adipsin, aP2, and acrp30, are not part of the PPAR $\gamma$-induced program in colon cancer cells; instead, genes characteristic of gut epithelium are in- 
Drori et al.

Figure 7. Ectopic expression of Hic-5 in 3T3-L1 preadipocytes inhibits adipocyte differentiation while inducing markers of epithelial gut differentiation. $(A)$ Hic-5 mRNA levels during 3T3-L1 adipogenesis were analyzed using real-time RT-PCR. (B) 3T3-L1 preadipocytes were infected with either retrovirus expressing Hic-5 or an empty retrovirus. Cells were then differentiated using a standard protocol with addition of rosiglitazone. After $4 \mathrm{~d}$ cells were fixed, and phase-contrast pictures were taken (top panel) or stained for lipid droplet formation by Oil-Red-O (bottom panel). (C) 3T3-L1 preadipocytes were treated as described in $B$. After $4 \mathrm{~d}$ of differentiation with or without rosiglitazone, cells were harvested and RNA was extracted. Levels of mRNA for adipocyte markers adipsin, acrp30, and aP2 and gut epithelial markers KLF4 L-FABP and keratin 20 were determined by real-time quantitative RT-PCR. Statistical analysis was done using Student's $t$-test. $\left({ }^{\star}\right)$ $p<0.05$. (D) Illustration of Hic-5 and PPAR $\gamma$ combination in epithelial differentiation.

A

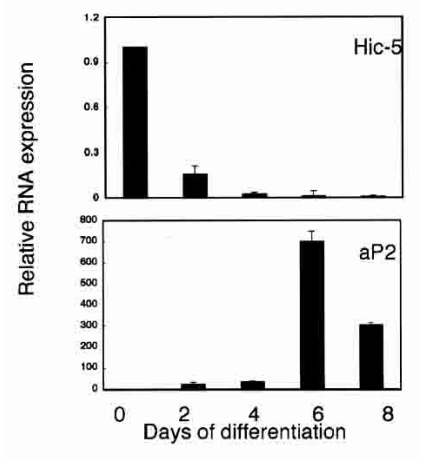

B

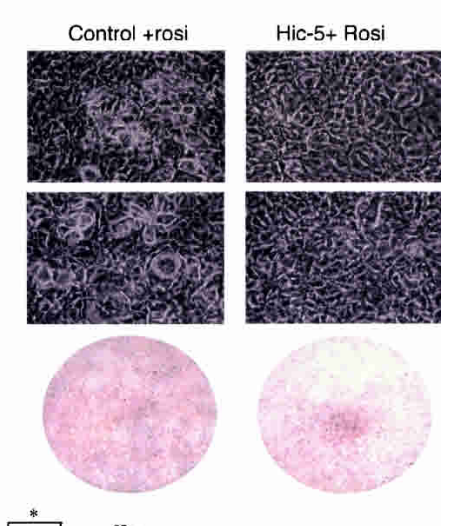

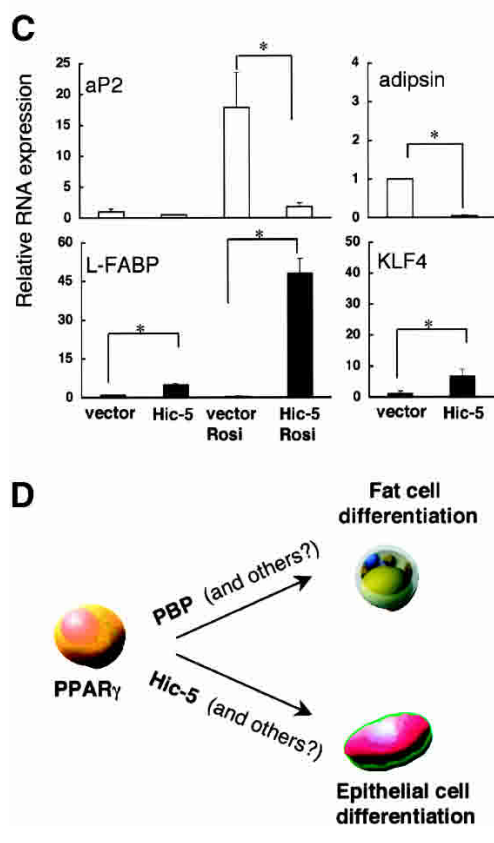

duced when PPAR $\gamma$ is activated in this cell type. Since PPAR $\gamma$ itself is apparently identical in both differentiation processes, as far as is known, it is likely that another level of regulation is involved. There are now several well-documented examples of tissue-specific coactivators that are major regulators of different metabolic and cell differentiation programs, such as OcaB (Luo and Roeder 1995; Kim et al. 1996), myocardin (Wang et al. 2001), and PGC-1 $\alpha$ (Puigserver et al. 1998; Yoon et al. 2001). We show here that Hic-5 collaborates with PPAR $\gamma$ to induce a program of epithelial-specific gene expression. Of particular interest, the combination of Hic-5 and a PPAR $\gamma$ agonist facilitates the induction of certain epithelial markers and inhibits fat differentiation, even in determined preadipocytes, (this is shown schematically in Fig. 7D). We also show here that Hic-5 and PPAR $\gamma$ are coexpressed in the gut during embryonic development and that this expression coincides with differentiation/ emergence of definitive epithelial cells (Fig. 2A,B). Furthermore, the gene expression pattern in small intestine epithelium of $\operatorname{PPAR} \gamma^{+/-}$mice showed a decrease in epithelial markers. Similar results are obtained here by using siRNA against Hic-5 in an ex vivo model of fetal gut

development. Conversely, introduction of a vector expressing Hic-5 resulted in an increase in epithelial marker mRNAs (Fig. 6). These data, taken together, strongly suggest that the molecular partnership between PPAR $\gamma$ and Hic-5 has physiological significance in gut development.

Hic-5, a member of the LIM domain family with striking similarity to paxillin (Shibanuma et al. 1994; Yuminamochi et al. 2003), can shuttle between focal adhesions and the nucleus, suggesting a possible role in relaying cytoplasmic signals into the nucleus (Shibanuma et al. 2003). LIM domain are implicated in various biological processes, including cell lineage determination and organ development (for reviews, see Bach 2000; Gill 2003). Hic-5, in particular, was previously shown to be expressed in epithelial cells (Zhang et al. 2000) and correlated with differentiation processes induced by retinoic acid (Shibanuma and Nose 1998). Indeed, all the genes we examined here that are induced through the combination of Hic-5 and PPAR $\gamma$ are related to gut epithelial differentiation. Keratin 20 belongs to the large family of cytokeratins that are expressed almost exclusively in epithelial cells, in this case mainly in mature 
gastrointestinal epithelium, urothelium, and Merkel cells (Moll et al. 1990); keratin 20 expression is also used to distinguish colon from other cancers in clinical pathology (Nishizuka et al. 2003). L-FABP, a fatty-acidbinding protein, is highly expressed in hepatocytes and enterocytes and is an established marker of intestinal epithelial differentiation and development (Roth et al. 1990). KLF4 is a zinc-finger transcription factor that is enriched in postmitotic gut epithelial cells (Dang et al. 2003; Hinnebusch et al. 2004; Zhao et al. 2004) and required for goblet cell differentiation in the colon (Katz et al. 2002). Importantly, robust induction of these genes required the combined activity of PPAR $\gamma$ and Hic-5; expression of Hic-5 alone was not sufficient to activate this program.

Hic-5 has also been implicated in tumorogenesis, although the published literature is ambivalent about its precise role. Hic-5 (ARA55) activates the androgen receptor in prostate cancer and was therefore initially suggested to promote prostate cancer cell growth (Fujimoto et al. 1999; Rahman et al. 2003). However, it was reported more recently that expression of ARA55 (Hic-5), but not that of other androgen receptor coactivators such as ARA54 or ARA70, is decreased in prostate tumors (Mestayer et al. 2003). Consistent with these data, we show in this study that Hic-5 expression is also decreased in AOM-induced colon tumors, further suggesting that Hic-5 is unlikely to be a positive effector of carcinoma progression. The fact that Hic-5 and PPAR $\gamma$ collaborate to induce expression of L-FABP, keratin 20, and KLF4, markers of gut maturation, is more consistent with a role for Hic-5 as a tumor suppressor.

Finally, our data suggest a molecular mechanism by which the tumor suppressor activities of TGF $\beta$ and PPAR $\gamma$ may be integrated. Hic-5 was originally isolated as a TGF $\beta$-inducible gene (Shibanuma et al. 1994), and TGF $\beta$ regulates a well-established tumor-suppressor signaling pathway in colon cancer that enhances epithelial differentiation and inhibits cell growth. In advanced stages of colon cancer, aberrant TGF $\beta$ signaling can enhance malignancy, epithelial to mesenchymal transition (EMT), and metastasis (for reviews, see Akhurst and Derynck 2001; Derynck et al. 2001). Genetic studies, including in human colon cancer patients (Sarraf et al. 1999|, implicate PPAR $\gamma$ as a tumor suppressor. PPAR $\gamma$ also regulates cancer cell growth and differentiation in vitro (Sarraf et al. 1998; Gupta et al. 2003). Much like TGF $\beta$, PPAR $\gamma$ has also been shown to be an effective tumor suppressor in the colon early in the process of carcinogenesis. In the presence of damage to the APC gene, PPAR $\gamma$ lost its protective function (Girnun et al. 2002) or even enhanced cancer progression (Lefebvre et al. 1998; Saez et al. 1998). It therefore seems likely that induction of Hic-5 by TGF $\beta$ enhances the ability of $\operatorname{PPAR} \gamma$ to modulate the program of epithelial differentiation in vivo.

Mechanism-based strategies to promote tumor differentiation represent a promising new area in cancer research. The best example of differentiation therapy to date is the use of all-trans-retinoic acid (ATRA) to treat acute promyelocytic leukemia (APL) (Zelent et al. 2001; Fang et al. 2002; Tallman 2004). The ability of ATRA to induce terminal differentiation of malignant myeloid cells to mature neutrophils depends on the expression of a chimeric PML-RAR $\alpha$ fusion protein resulting from a $\mathrm{t}(15 ; 17)$ chromosomal translocation (Zelent et al. 2001; Fang et al. 2002; Tallman 2004). By analogy, the use of PPAR $\gamma$ agonists in differentiation therapy has thus far shown promising results in certain liposarcoma patients, where rosiglitazone induced terminal adipocytic differentiation and tumor regression (Demetri et al. 1999). While clinical trails of PPAR $\gamma$ agonists as the sole therapy in advanced epithelial tumors to date have failed to show significant clinical effects (Kulke et al. 2002), new trials will likely combine PPAR $\gamma$ ligands with other chemotherapy agents. This study suggests that agonists that enhance interaction of PPAR $\gamma$ with Hic-5 could be useful in differentiation therapy of colon and other epithelial cancers.

\section{Materials and methods}

\section{Yeast two-hybrid screening}

A cDNA encoding amino acids 183-505 of the murine PPAR $\gamma$ was cloned in-frame into the GAL4 DNA-binding domain of pGBKT7 (pGBKT7-PPAR $\gamma$, Clontech). An SW480 colon cancer cell cDNA expression library was constructed into the pGAD10 plasmid expressing the GAL4 activation domain (custom generation, Clontech). A yeast two-hybrid screening was performed as described in the Clontech Matchmaker two-hybrid system protocol. Briefly, pGBKT7-PPAR $\gamma$ was transformed into Y190 yeast cells by the lithium acetate method and maintained by selection (Y190-PPAR $\gamma$ ). The pGAD10 plasmid containing the colon cancer cell cDNA library was transformed into Y190PPAR $\gamma$ yeast cells, and positive clones were assayed for $\beta$-galactosidase activity in a filter assay as described in the Clontech protocol.

\section{Cell culture and transient transfection/reporter assays}

293T, Cos-1, Bosc, 3T3-L1, and Moser colon cancer cell lines were cultured in DMEM containing 10\% FBS supplemented with penicillin/streptomycin. Sf21 insect cells were cultured in Grace's insect media containing 10\% FBS. Bosc or Cos- 1 cells were transiently transfected with a PPAR $\gamma$ expression vector; a PPAR $\gamma$ response element fused to a luciferase construct (DR1luc); and either a control vector, vectors expressing Hic-5, and/ or Hic-5 deletion constructs or PGC- $1 \alpha$ expression constructs using Superfect transfection reagent (Qiagen). Cells were treated with various ligand concentrations, and luciferase levels were assayed after 18-24 h of ligand exposure.

\section{Protein interaction analysis}

Bosc cells were transfected with a control vector, vectors expressing Flag-PPAR $\gamma$, or gfp-PGC1 $\alpha$ as a positive control. Cell lysates were incubated with agarose beads bound to an anti-Flag antibody (Sigma) in the presence or absence of rosiglitazone. Beads were washed and proteins separated on an $8 \%$ gel by PAGE and transferred to PVDF. Immunoblotting was performed using antibodies against Hic-5 (BD Transduction Labs), PPAR $\gamma$ (Santa Cruz Biotech), or gfp (a kind gift from Dr. Pam Silver, 
Dana-Farber Cancer Institute, Boston, MA). GST-PPAR $\gamma$ was produced using a baculovirus expression system. A cDNA expressing full-length PPAR $\gamma$ was cloned into a pAcGHLT baculovirus expression plasmid (Pharmingen). Sf21 cells were infected with the baculovirus expressing GST-PPAR $\gamma$ for $2 \mathrm{~d}$ and then harvested into lysis buffer. GST-PPAR $\gamma$ protein was isolated by incubation with GSH-Sepharose beads and protein quantified by Commassie blue staining. Affinity purification was performed using $1 \mu \mathrm{g}$ GST-PPAR $\gamma$ protein with cell lysate from Bosc cells transfected full-length gfp-Hic-5 or an N-terminal or C-terminal gfp-Hic-5 deletion constructs (gfp-Nterm and gfp-Cterm, respectively) as shown in Figure 1C (a kind gift from Drs. Nose and Shibanuma, Showa University School of Pharmaceutical Sciences, Tokyo, Japan) (Fujita et al. 1998). Briefly, GST-PPAR $\gamma$ bound to GSH beads was incubated for $2 \mathrm{~h}$ with cell lysates at $25^{\circ} \mathrm{C}$. Beads were washed and proteins resolved on an $8 \%$ SDS gel. Proteins were transferred to PVDF and immunoblotted using an antibody against gfp (a kind gift from Dr. Pam Silver). Mapping of Hic-5 domains that interact with PPAR $\gamma$ was performed by using full-length Hic- 5 or Hic- 5 deletion constructs, as shown in Figure 1D (a kind gift from Drs. Nose and Shibanuma), or SRC-1 as a positive control. Proteins were translated in vitro in the presence of ${ }^{35} \mathrm{~S}$-methionine according to manufacturer protocol (Promega). GST-PPAR $\gamma$ bound to GSH beads was incubated with in vitro translated protein in binding buffer at room temperature for $1 \mathrm{~h}$. Following washing, proteins were eluted and resolved on a $4 \%-12 \%$ gel (Invitrogen) by PAGE. Gels were dried down and exposed to film.

\section{Retroviral preparation and infections}

A full-length Hic-5 cDNA was generated by RT-PCR from mouse spleen RNA using Invitrogens TOPO cloning kit. The resulting cDNA was sequenced and subsequently cloned into a pMSCV retroviral vector (Clontech). siRNA against Hic-5 was designed using Oligoengines online design program. The 293T packaging cell line was transfected using Lipofectamine 2000 (Invitrogen). Cells were transfected with expression vectors for vsv and gag-pol and with the following retroviral vectors: $\mathrm{pBabe}$ expressing gfp, gfp-Hic-5, or gfp-Nterm, pmscv-puro, pmscvpuro expressing Hic-5, pSuperRetro-neo control, or pSuperRetro-neo siRNA against Hic-5. After 6-12 h, media was replaced, and cells were transferred to $33^{\circ} \mathrm{C}$ for $24-72 \mathrm{~h}$. Viral supernatants were collected and filtered. Moser or 3T3-L1 cells were plated and infected on the following day with the viral supernatants and $8 \mu \mathrm{g} / \mathrm{mL}$ polybrene. 3T3-L1 cells were subjected to a differentiation protocol when confluent (see below). Moser cells were split 1:3 and selected with either puromycin or neomycin for $1 \mathrm{wk}$, or sorted for gfp-expressing cells.

\section{Adipocyte differentiation and Oil-Red-O staining}

For differentiation assays, confluent 3T3-L1 cells infected with control or Hic-5 expressing retrovirus were treated with or without $1 \mu \mathrm{M}$ rosiglitazone plus $0.5 \mathrm{mM} 3$-isobutyl-1-methylxanthine, $5 \mu \mathrm{g} / \mathrm{mL}$ insulin, and $1 \mu \mathrm{M}$ dexamethasone for $2 \mathrm{~d}$. Cells were then kept in maintenance medium (with or without rosiglitazone) consisting of DMEM with $10 \%$ FBS supplemented with penicillin/streptomycin and $5 \mu \mathrm{g} / \mathrm{mL}$ insulin. RNA was harvested and cDNA prepared as described below. Differentiated 3T3-L1 cells were also washed in PBS and then fixed in $10 \%$ buffered formalin (Formaldefresh; Fisher). A stock solution of $0.5 \%$ Oil-Red-O (Sigma) in isopropanol (w/v) was diluted 60 : 40 in water, filtered, and added to fixed cells. Cells were then washed in water and photographed.

\section{Preparation of tissue for RNA and immunohistochemistry}

Small intestines were isolated from either E12.5-E17.5 mouse embryos as previously described (Tou et al. 2004), or from adult mice. For immunohistochemistry analysis, isolated small intestine was rinsed with PBS and fixed in $4 \%$ paraformaldehyde (EM sciences). Paraffin embedding, sectioning, and immunohistochemistry were performed by the Pathology Core at Brigham and Women's Hospital. A mouse-on-mouse kit was used for Hic-5 antibody staining (Vector labs). Immunohistochemistry was performed using an anti-mouse monoclonal against Hic-5 $(1: 100)$ and an anti-rabbit polyclonal antibody against PPAR $\gamma$ (1:200). For gene expression analysis, RNA was isolated, cDNA was synthesized, and mRNA levels were analyzed using realtime PCR analysis. For tumor analysis, 8-wk-old C57Bl/6J mice were treated with the colon-specific carcinogen AOM as previously described (Burdette Walter 1970; Girnun et al. 2002). Tumor and adjacent uninvolved tissue were excised and snap frozen in liquid nitrogen. RNA isolation, cDNA synthesis, and real-time PCR analysis of tumor, normal adjacent and embryonic tissues were performed as described below.

\section{Ex vivo embryonic gut development}

Day 12.5 fetal mouse intestines were isolated under a dissecting microscope as previously described (Tou et al. 2004). Briefly, to introduce expression vector into explants, $2 \mu \mathrm{g}$ of control plasmid or plasmid encoding either Hic- 5 or siRNA directed against Hic-5 was injected into the intestinal lumen by using a capillary pipette and Nanoject injection device. Explants were bathed in DMEM, placed between platinum electrodes and exposed to three 10-msec pulses of $60 \mathrm{~V}$ each by using the BTX830 squarewave pulse electroporator, washed in DMEM, and cultured. After $2 \mathrm{~d}$ in culture, explants were harvested in RIPA buffer for protein analysis or subjected to RNA isolation using Trizol.

\section{Transcriptional profiling}

Moser human colon cancer cells were treated for $14 \mathrm{~h}$ with vehicle control or $1 \mu \mathrm{M}$ rosiglitazone. Total RNA was prepared using an RNeasy Mini Kit (Qiagen Inc.) and used for global expression analysis. Affymetrix array hybridization and scanning were performed by the Core Facility at Dana-Farber Cancer Institute using human genome U133A chip (Affymetrix). Array data were analyzed with d-CHIP array analysis program (Li and Wong 2001).

\section{Real-time PCR}

Total RNA was prepared from cells or tissues using Trizol reagent (Invitrogen) following the manufacturer's instructions. Briefly, chloroform was added to homogenized samples, and the aqueous layer was isolated following centrifugation. RNA was precipitated with isopropanol and washed in $70 \%$ ethanol. One microgram of total RNA was DNase treated, and cDNA was synthesized using iScript reverse transcriptase reagent (BioRad). PCR reactions were performed using SYBR Green PCR Master Mix (Bio-Rad). Real-time PCR reactions were carried out using the following conditions: for $2 \mathrm{~min}$ at $50^{\circ} \mathrm{C}$ and for $10 \mathrm{~min}$ at $95^{\circ} \mathrm{C}$, followed by 40 cycles of switching between $95^{\circ} \mathrm{C}$ for 15 sec and $60^{\circ} \mathrm{C}$ for $1 \mathrm{~min}$ (iCycler, Bio-Rad). The cDNA synthesis step included a control reaction without the reverse transcriptase, and the PCR step included a control reaction without the template to rule out contamination and/or genomic amplification. In addition, the TATA-box-binding protein (TBP) gene was used as a control to account for possible variations in initial 
RNA quantity and efficiency of the cDNA synthesis reaction. Primers for target genes were designed using the PRIMEREXPRESS software (Applied Biosystems). Sequences for real-time PCR primers are available upon request.

\section{Acknowledgments}

We thank Drs. Kiyoshi Nose and Motoko Shibanuma for Hic-5 plasmids, Dr. Frank Gonzalez for PPAR $\gamma$ targeted mice, Dr. Pam Silver for GFP antibody, and Dr. Marc Montminy for adenovirus expressing siRNA against PGCl $\alpha$. We extend our appreciation to the Dana-Farber Cancer Institute Microarray Core for expert processing of RNA samples, and Flow Cytometry Core for FACS analysis and the Pathology Core at Brigham and Women's Hospital for processing immunohistochemistry of mice samples. We also thank Dr. Sibylle Jaeger and Dr. Christopher Walkey for helpful discussions and careful reading the manuscript, Dr. Melina Fan for real-time PCR data on PGC1 $\alpha$, and Adah Levens for administrative assistance. This work was supported by NIH grants RO1DK57670 (B.M.S), DK064685 (G.D.G)., and RO1DK61139 (R.A.S). S.D was supported by a grant from Friends of the Dana-Farber Cancer Institute and by the ADA Mentor based Postdoctoral Fellowship.

\section{References}

Akhurst, R.J. and Derynck, R. 2001. TGF- $\beta$ signaling in cancer: A double-edged sword. Trends Cell. Biol. 11: S44-S51.

Akiyama, T.E., Sakai, S., Lambert, G., Nicol, C.J., Matsusue, K., Pimprale, S., Lee, Y.H., Ricote, M., Glass, C.K., Brewer Jr., H.B., et al. 2002. Conditional disruption of the peroxisome proliferator-activated receptor $\gamma$ gene in mice results in lowered expression of ABCA1, ABCG1, and apoE in macrophages and reduced cholesterol efflux. Mol. Cell. Biol. 22: 2607-2619.

Bach, I. 2000. The LIM domain: Regulation by association. Mech. Dev. 91: 5-17.

Barak, Y., Nelson, M.C., Ong, E.S., Jones, Y.Z., Ruiz-Lozano, P., Chien, K.R., Koder, A., and Evans, R.M. 1999. PPAR $\gamma$ is required for placental, cardiac, and adipose tissue development. Mol. Cell 4: 585-595.

Burdette Walter, J. 1970. Carcinoma of the colon and antecedent epithelium. Cancer Res. 30: 253-256.

Burstein, H.J., Demetri, G.D., Mueller, E., Sarraf, P., Spiegelman, B.M., and Winer, E.P. 2003. Use of the peroxisome proliferator-activated receptor (PPAR) $\gamma$ ligand troglitazone as treatment for refractory breast cancer: A phase II study. Breast Cancer Res. Treat. 79: 391-397.

Calnek, D. and Quaroni, A. 1993. Differential localization by in situ hybridization of distinct keratin mRNA species during intestinal epithelial cell development and differentiation. Differentiation 53: 95-104.

Chen, X., Whitney, E.M., Gao, S.Y., and Yang, V.W. 2003. Transcriptional profiling of Kruppel-like factor 4 reveals a function in cell cycle regulation and epithelial differentiation. $J$. Mol. Biol. 326: 665-677.

Dang, D.T., Chen, X., Feng, J., Torbenson, M., Dang, L.H., and Yang, V.W. 2003. Overexpression of Kruppel-like factor 4 in the human colon cancer cell line RKO leads to reduced tumorigenecity. Oncogene 22: 3424-3430.

Demetri, G.D., Fletcher, C.D., Mueller, E., Sarraf, P., Naujoks, R., Campbell, N., Spiegelman, B.M., and Singer, S. 1999. Induction of solid tumor differentiation by the peroxisome proliferator-activated receptor- $\gamma$ ligand troglitazone in patients with liposarcoma. Proc. Nat1. Acad. Sci. 96: 3951-3956.

Derynck, R., Akhurst, R.J., and Balmain, A. 2001. TGF- $\beta$ signaling in tumor suppression and cancer progression. Nat. Genet. 29: 117-129.

Fang, J., Chen, S.J., Tong, J.H., Wang, Z.G., Chen, G.Q., and Chen, Z. 2002. Treatment of acute promyelocytic leukemia with ATRA and As2O3: A model of molecular target-based cancer therapy. Cancer Biol. Ther. 1: 614-620.

Feilchenfeldt, J., Brundler, M.A., Soravia, C., Totsch, M., and Meier, C.A. 2004. Peroxisome proliferator-activated receptors (PPARs) and associated transcription factors in colon cancer: Reduced expression of PPAR $\gamma$-coactivator 1 (PGC-1). Cancer Lett. 203: 25-33.

Forman, B.M., Tontonoz, P., Chen, J., Brun, R.P., Spiegelman, B.M., and Evans, R.M. 1995. 15-Deoxy- $\delta$ 12, 14-prostaglandin $\mathrm{J} 2$ is a ligand for the adipocyte determination factor PPAR $\gamma$. Cell 83: 803-812.

Fujimoto, N., Yeh, S., Kang, H.Y., Inui, S., Chang, H.C., Mizokami, A., and Chang, C. 1999. Cloning and characterization of androgen receptor coactivator, ARA55, in human prostate. J. Biol. Chem. 274: 8316-8321.

Fujita, H., Kamiguchi, K., Cho, D., Shibanuma, M., Morimoto, C., and Tachibana, K. 1998. Interaction of Hic-5, A senescence-related protein, with focal adhesion kinase. J. Biol. Chem. 273: 26516-26521.

Gill, G.N. 2003. Decoding the LIM development code. Trans. Am. Clin. Climatol. Assoc. 114: 179-189.

Girnun, G.D., Smith, W.M., Drori, S., Sarraf, P., Mueller, E., Eng, C., Nambiar, P., Rosenberg, D.W., Bronson, R.T., Edelmann, W., et al. 2002. APC-dependent suppression of colon carcinogenesis by PPAR y. Proc. Nat1. Acad. Sci. 99: 1377113776.

Gupta, R.A., Brockman, J.A., Sarraf, P., Willson, T.M., and DuBois, R.N. 2001. Target genes of peroxisome proliferator-activated receptor $\gamma$ in colorectal cancer cells. J. Biol. Chem. 276: 29681-29687.

Gupta, R.A., Sarraf, P., Mueller, E., Brockman, J.A., Prusakiewicz, J.J., Eng, C., Willson, T.M., and DuBois, R.N. 2003. Peroxisome proliferator-activated receptor $\gamma$-mediated differentiation: A mutation in colon cancer cells reveals divergent and cell type-specific mechanisms. J. Biol. Chem. 278: 22669-22677.

Hanks, S.K., Ryzhova, L., Shin, N.Y., and Brabek, J. 2003. Focal adhesion kinase signaling activities and their implications in the control of cell survival and motility. Front. Biosci. 8: d982-d996.

Hinnebusch, B.F., Siddique, A., Henderson, J.W., Malo, M.S., Zhang, W., Athaide, C.P., Abedrapo, M.A., Chen, X., Yang, V.W., and Hodin, R.A. 2004. Enterocyte differentiation marker intestinal alkaline phosphatase is a target gene of the gut-enriched Kruppel-like factor. Am. I. Physiol. Gastrointest. Liver Physiol. 286: G23-G30.

Hu, E., Tontonoz, P., and Spiegelman, B.M. 1995. Transdifferentiation of myoblasts by the adipogenic transcription factors PPAR $\gamma$ and C/EBP $\alpha$. Proc. Natl. Acad. Sci. 92: 98569860.

Karasik, A., Pepinsky, R.B., Shoelson, S.E., and Kahn, C.R. 1988. Lipocortins 1 and 2 as substrates for the insulin receptor kinase in rat liver. J. Biol. Chem. 263: 11862-11867.

Kasai, M., Guerrero-Santoro, J., Friedman, R., Leman, E.S., Getzenberg, R.H., and DeFranco, D.B. 2003. The Group 3 LIM domain protein paxillin potentiates androgen receptor transactivation in prostate cancer cell lines. Cancer Res. 63: 4927-4935.

Katz, J.P., Perreault, N., Goldstein, B.G., Lee, C.S., Labosky, P.A., Yang, V.W., and Kaestner, K.H. 2002. The zinc-finger 
transcription factor Klf4 is required for terminal differentiation of goblet cells in the colon. Development 129: 26192628.

Kim, U., Qin, X.F., Gong, S., Stevens, S., Luo, Y., Nussenzweig, M., and Roeder, R.G. 1996. The B-cell-specific transcription coactivator OCA-B/OBF-1/Bob-1 is essential for normal production of immunoglobulin isotypes. Nature 383: 542-547.

Koeffler, H.P. 2003. Peroxisome proliferator-activated receptor $\gamma$ and cancers. Clin. Cancer Res. 9: 1-9.

Koo, S.H., Satoh, H., Herzig, S., Lee, C.H., Hedrick, S., Kulkarni, R., Evans, R.M., Olefsky, J., and Montminy, M. 2004. PGC-1 promotes insulin resistance in liver through PPAR- $\alpha$-dependent induction of TRB-3. Nat. Med. 10: 530-534.

Kubota, T., Koshizuka, K., Williamson, E.A., Asou, H., Said, J.W., Holden, S., Miyoshi, I., and Koeffler, H.P. 1998. Ligand for peroxisome proliferator-activated receptor $\gamma$ (troglitazone) has potent antitumor effect against human prostate cancer both in vitro and in vivo. Cancer Res. 58: 3344-3352.

Kubota, N., Terauchi, Y., Miki, H., Tamemoto, H., Yamauchi, T., Komeda, K., Satoh, S., Nakano, R., Ishii, C., Sugiyama, T., et al. 1999. PPAR $\gamma$ mediates high-fat diet-induced adipocyte hypertrophy and insulin resistance. Mol. Cell 4: 597-609.

Kulke, M.H., Demetri, G.D., Sharpless, N.E., Ryan, D.P., Shivdasani, R., Clark, J.S., Spiegelman, B.M., Kim, H., Mayer, R.J., and Fuchs, C.S. 2002. A phase II study of troglitazone, an activator of the PPAR $\gamma$ receptor, in patients with chemotherapy-resistant metastatic colorectal cancer. Cancer I. 8: 395-399.

Lefebvre, A.M., Chen, I., Desreumaux, P., Najib, J., Fruchart, J.C., Geboes, K., Briggs, M., Heyman, R., and Auwerx, J. 1998. Activation of the peroxisome proliferator-activated receptor $\gamma$ promotes the development of colon tumors in C57BL/6J-APCMin/+ mice. Nat. Med. 4: 1053-1057.

Lefebvre, M., Paulweber, B., Fajas, L., Woods, J., McCrary, C., Colombel, J.F., Najib, J., Fruchart, J.C., Datz, C., Vidal, H., et al. 1999. Peroxisome proliferator-activated receptor $\gamma$ is induced during differentiation of colon epithelium cells. J. Endocrinol. 162: 331-340.

Lehmann, J.M., Moore, L.B., Smith-Oliver, T.A., Wilkison, W.O., Willson, T.M., and Kliewer, S.A. 1995. An antidiabetic thiazolidinedione is a high affinity ligand for peroxisome proliferator-activated receptor $\gamma($ PPAR $\gamma)$. J. Biol. Chem. 270: $12953-12956$.

Li, J. and Wong, L. 2001. Emerging patterns and gene expression data. Genome Inform. Ser. Workshop Genome Inform. 12: 3-13.

Lowell, B.B. 1999. PPAR $\gamma$ : An essential regulator of adipogenesis and modulator of fat cell function. Cell 99: 239-242.

Luo, Y. and Roeder, R.G. 1995. Cloning, functional characterization, and mechanism of action of the B-cell-specific transcriptional coactivator OCA-B. Mol. Cell. Biol. 15: 41154124.

Mansen, A., Guardiola-Diaz, H., Rafter, J., Branting, C., and Gustafsson, J.A. 1996. Expression of the peroxisome proliferator-activated receptor (PPAR) in the mouse colonic mucosa. Biochem. Biophys. Res. Commun. 222: 844-851.

Mestayer, C., Blanchere, M., Jaubert, F., Dufour, B., and Mowszowicz, I. 2003. Expression of androgen receptor coactivators in normal and cancer prostate tissues and cultured cell lines. Prostate 56: 192-200.

Michalik, L., Desvergne, B., and Wahli, W. 2004. Peroxisomeproliferator-activated receptors and cancers: Complex stories. Nat. Rev. Cancer 4: 61-70.

Moll, R., Schiller, D.L., and Franke, W.W. 1990. Identification of protein IT of the intestinal cytoskeleton as a novel type I cytokeratin with unusual properties and expression pat- terns. J. Cell. Biol. 111: 567-580.

Moll, R., Zimbelmann, R., Goldschmidt, M.D., Keith, M., Laufer, J., Kasper, M., Koch, P.J., and Franke, W.W. 1993. The human gene encoding cytokeratin 20 and its expression during fetal development and in gastrointestinal carcinomas. Differentiation 53: 75-93.

Mueller, E., Sarraf, P., Tontonoz, P., Evans, R.M., Martin, K.J., Zhang, M., Fletcher, C., Singer, S., and Spiegelman, B.M. 1998. Terminal differentiation of human breast cancer through PPAR $\gamma$. Mol. Cell 1: 465-470.

Mueller, E., Smith, M., Sarraf, P., Kroll, T., Aiyer, A., Kaufman, D.S., Oh, W., Demetri, G., Figg, W.D., Zhou, X.P., et al. 2000. Effects of ligand activation of peroxisome proliferator-activated receptor $\gamma$ in human prostate cancer. Proc. Natl. Acad. Sci. 97: 10990-10995.

Muller, J.M., Isele, U., Metzger, E., Rempel, A., Moser, M., Pscherer, A., Breyer, T., Holubarsch, C., Buettner, R., and Schule, R. 2000. FHL2, a novel tissue-specific coactivator of the androgen receptor. EMBO J. 19: 359-369.

Nishizuka, S., Chen, S.T., Gwadry, F.G., Alexander, J., Major, S.M., Scherf, U., Reinhold, W.C., Waltham, M., Charboneau, L., Young, L., et al. 2003. Diagnostic markers that distinguish colon and ovarian adenocarcinomas: Identification by genomic, proteomic, and tissue array profiling. Cancer Res. 63: $5243-5250$.

Puigserver, P., Wu, Z., Park, C.W., Graves, R., Wright, M., and Spiegelman, B.M. 1998. A cold-inducible coactivator of nuclear receptors linked to adaptive thermogenesis. Cell 92: 829-839.

Rahman, M.M., Miyamoto, H., Lardy, H., and Chang, C. 2003. Inactivation of androgen receptor coregulator ARA55 inhibits androgen receptor activity and agonist effect of antiandrogens in prostate cancer cells. Proc. Natl. Acad. Sci. 100: 5124-5129.

Rosen, E.D., Sarraf, P., Troy, A.E., Bradwin, G., Moore, K., Milstone, D.S., Spiegelman, B.M., and Mortensen, R.M. 1999. PPAR $\gamma$ is required for the differentiation of adipose tissue in vivo and in vitro. Mol. Cell 4: 611-617.

Rosen, E.D., Walkey, C.J., Puigserver, P., and Spiegelman, B.M. 2000. Transcriptional regulation of adipogenesis. Genes \& Dev. 14: 1293-1307.

Roth, K.A., Hertz, J.M., and Gordon, J.I. 1990. Mapping enteroendocrine cell populations in transgenic mice reveals an unexpected degree of complexity in cellular differentiation within the gastrointestinal tract. J. Cell. Biol. 110: 17911801.

Saez, E., P. Tontonoz, P., Nelson, M.C., Alvarez, J.G., Ming, U.T., Baird, S.M., Thomazy, V.A., and Evans, R.M. 1998. Activators of the nuclear receptor PPAR $\gamma$ enhance colon polyp formation. Nat. Med. 4: 1058-1061.

Sarraf, P., Mueller, E., Jones, D., King, F.J., DeAngelo, D.J., Partridge, J.B., Holden, S.A., Chen, L.B., Singer, S., Fletcher, C., et al. 1998. Differentiation and reversal of malignant changes in colon cancer through PPAR $\gamma$. Nat. Med. 4: 1046-1052.

Sarraf, P., Mueller, E., Smith, W.M., Wright, H.M., Kum, J.B., Aaltonen, L.A., de la Chapelle, A., Spiegelman, B.M., and Eng, C. 1999. Loss-of-function mutations in PPAR $\gamma$ associated with human colon cancer. Mol. Cell 3: 799-804.

Schaller, M.D. 2001. Paxillin: A focal adhesion-associated adaptor protein. Oncogene 20: 6459-6472.

Schreiber, S.N., Knutti, D., Brogli, K., Uhlmann, T., Kralli, A. 2003. The transriptional coactivator PGC-1 regulates the expression and activity of the orphan nuclear receptor estrogren-related receptor $\alpha(\mathrm{ERR} \alpha)$. I. Biol. Chem. 278: 9013-9018.

Shibanuma, M. and Nose, K. 1998. Forced expression of hic-5, a 
senescence-related gene, potentiates a differentiation process of RCT-1 cells induced by retinoic acid. Int. J. Biochem. Cell. Biol. 30: 39-45.

Shibanuma, M., Mashimo, J., Kuroki, T., and Nose, K. 1994. Characterization of the TGF $\beta$ 1-inducible hic-5 gene that encodes a putative novel zinc finger protein and its possible involvement in cellular senescence. J. Biol. Chem. 269: 26767-26774.

Shibanuma, M., Kim-Kaneyama, J.R., Ishino, K., Sakamoto, N., Hishiki, T., Yamaguchi, K., Mori, K., Mashimo, J., and Nose, K. 2003. Hic-5 communicates between focal adhesions and the nucleus through oxidant-sensitive nuclear export signal. Mol. Biol. Cell 14: 1158-1171.

Simon, T.C. and Gordon, J.I. 1995. Intestinal epithelial cell differentiation: New insights from mice, flies and nematodes. Curr. Opin. Genet. Dev. 5: 577-586.

Spiegelman, B.M. 1998. PPAR- $\gamma$ : Adipogenic regulator and thiazolidinedione receptor. Diabetes 47: 507-514.

Tallman, M.S. 2004. Acute promyelocytic leukemia as a paradigm for targeted therapy. Semin. Hematol. 41: 27-32.

Tontonoz, P., Hu, E., and Spiegelman, B.M. 1994. Stimulation of adipogenesis in fibroblasts by PPAR $\gamma 2$, a lipid-activated transcription factor. Cell 79: 1147-1156.

Tou, L., Liu, Q., and Shivdasani, R.A. 2004. Regulation of mammalian epithelial differentiation and intestine development by class I histone deacetylases. Mol. Cell. Biol. 24: 31323139.

Wang, D., Chang, P.S., Wang, Z., Sutherland, L., Richardson, J.A., Small, E., Krieg, P.A., and Olson, E.N. 2001. Activation of cardiac gene expression by myocardin, a transcriptional cofactor for serum response factor. Cell 105: 851-862.

Yang, L., Guerrero, J., Hong, H., DeFranco, D.B., and Stallcup, M.R. 2000. Interaction of the tau 2 transcriptional activation domain of glucocorticoid receptor with a novel steroid receptor coactivator, Hic-5, which localizes to both focal adhesions and the nuclear matrix. Mol. Biol. Cell 11: 20072018.

Yoon, J.C., Puigserver, P., Chen, G., Donovan, J., Wu, Z., Rhee, J., Adelmant, G., Stafford, J., Kahn, C.R., Granner, D.K., et al. 2001. Control of hepatic gluconeogenesis through the transcriptional coactivator PGC-1. Nature 413: 131-138.

Yoshida, T., Sinha, S., Dandre, F., Wamhoff, B.R., Hoofnagle, M.H., Kremer, B.E., Wang, D.Z., Olson, E.N., and Owens, G.K. 2003. Myocardin is a key regulator of CArG-dependent transcription of multiple smooth muscle marker genes. Circ. Res. 92: 856-864.

Yuminamochi, T., Yatomi, Y., Osada, M., Ohmori, T., Ishii, Y., Nakazawa, K., Hosogaya, S., and Ozaki, Y. 2003. Expression of the LIM proteins paxillin and Hic-5 in human tissues. J. Histochem. Cytochem. 51: 513-521.

Zelent, A., Guidez, F., Melnick, A., Waxman, S., and Licht, J.D. 2001. Translocations of the RAR $\alpha$ gene in acute promyelocytic leukemia. Oncogene 20: 7186-7203.

Zhang, J., Zhang, L.X., Meltzer, P.S., Barrett, J.C., and Trent, J.M. 2000. Molecular cloning of human Hic-5, a potential regulator involved in signal transduction and cellular senescence. Mol. Carcinog. 27: 177-183.

Zhao, W., Hisamuddin, I.M., Nandan, M.O., Babbin, B.A., Lamb, N.E., and Yang, V.W. 2004. Identification of Kruppellike factor 4 as a potential tumor suppressor gene in colorectal cancer. Oncogene 23: 395-402. 


\section{Erratum}

Genes \& Development 19: 362-375 (2005)

Hic-5 regulates an epithelial program mediated by PPAR $\gamma$

Stavit Drori, Geoffrey D. Girnun, Liqiang Tou, Jeffrey D. Szwaya, Elisabetta Mueller, Xia Kia,

Ramesh A. Shivdasani, and Bruce M. Spiegelman

In the above-mentioned paper, the name of one of the authors was not presented correctly. Xia Kia should have appeared as Kai Xia. 


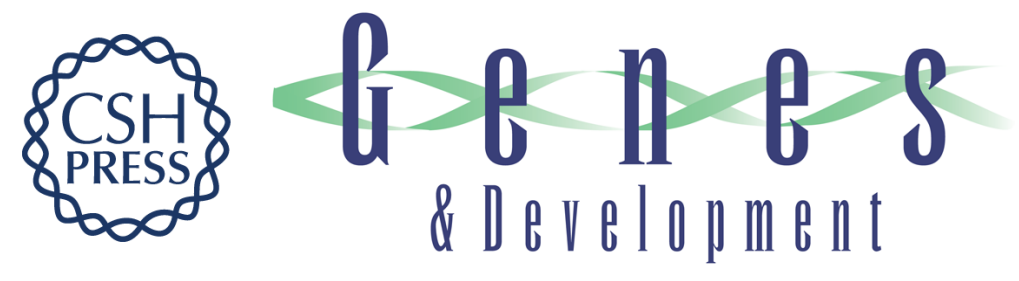

\section{Hic-5 regulates an epithelial program mediated by PPAR $\gamma$}

Stavit Drori, Geoffrey D. Girnun, Liqiang Tou, et al.

Genes Dev. 2005, 19:

Access the most recent version at doi:10.1101/gad.1240705

\footnotetext{
Supplemental http://genesdev.cshlp.org/content/suppl/2005/01/13/19.3.362.DC1

Material http://genesdev.cshlp.org/content/suppl/2005/02/18/19.3.362.DC2

Related Content Errata for vol. 19, p. 362

Genes Dev. April , 2005 19: 875

References This article cites 73 articles, 31 of which can be accessed free at: http://genesdev.cshlp.org/content/19/3/362.full.html\#ref-list-1

Articles cited in:

http://genesdev.cshlp.org/content/19/3/362.full.html\#related-urls

License

Email Alerting Receive free email alerts when new articles cite this article - sign up in the box at the top Service right corner of the article or click here.
}

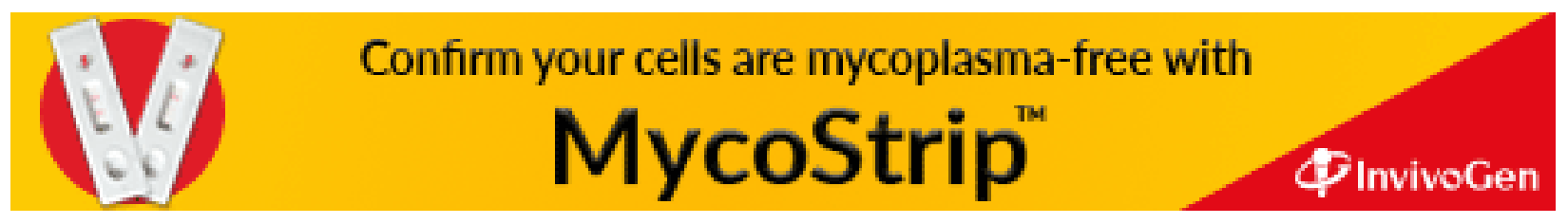

